\title{
Medya Çalışmalarında Geriye Dönük Yeniden Okumalar: (Deleuze Sonrası) Kant ve Film
}

\begin{abstract}
Güven Özdoyran*
Öz

Hareketli görüntü olarak filmin "ne" olduğunu ve/veya ne anlama geldiğini açıklamaya yönelik argümanlar genel olarak iki hat üzerinden açmaza girerler. Bunlardan ilkinde, film, kendisini teknik olarak üreten sinematik aygıta (apparatus) hapsedilir. Bu anlamıyla film, insanın zihinsel algı mekanizmasının "mimetik-mekanik tekrarı" olarak kavranır ve bu "taklit" ilişkisini aşamaz. Laura Mulvey'in formüle ettiği ve izleyiciyi merkezine alan ikinci paradigmada ise, film ve film izleme deneyimi neredeyse bir patolojiye işaret eden "voyeristik" ilişkiye indirgenir. Öte yandan Gilles Deleuze yeni bir tür "film teorisi" inşa ederken söz konusu iki yönelimi bütünüyle dışlayan ve filme yönelik çok daha "üretken" bir okumaya girişir. Böylece, "bir filmden neden keyif aldığımız" sorusunun cevabını "olumsuz" olmayan bir biçimde verme imkânına da sahip oluruz. Hareketli görüntü olarak film, hem içinde var olduğu -ya da "salındığı"hem de kendisinin ürettiği "zaman" bağlamında muamma bir entite olarak zihinlere sirayet etmeye aralıksız olarak devam eder. Bu makalenin temel iddiası ise, film fenomenini ve filme içkin bu türden eşsiz bir "zaman" kavramını veya "zamansallığı" kavrama çabasında, Immaunel Kant'ın estetik kuramının okuyucuya yeni bir alan açabileceğine yöneliktir. Kant'ın estetik teorisinin kendine münhasır doğası, hareketli görüntü olarak filmin ve onun 'zaman'ının "ne" olduğuna yönelik sınırlandırıcı/indirgemeci olmayan yeni ve üretken bir okuma yapmamızın imkânını sağlar. Bununla ilgili olarak, Kant'ın estetik teorisine "içkin” zaman anlayışının, filmin ürettiği/içerdiği zaman'ın dışında konumlanamayacağı iddiası makalede tartışmaya açılacaktır. Böylece, "bir filmden neden keyif aldığımız" sorusuna, Deleuze ile paralel bir biçimde, "bakışı ya da görmeyi kolonize eden" mekanizmayı dışarıda bırakarak cevap verme olanağına sahip oluruz. Bütün bu tartışmalar ışı̆̆ında bu makalede, filme yönelik daha önceki açıklama modellerinin görmezden geldiği “anomalilerin”, Kant'ın epistemolojisi ile estetik teorisi arasındaki sınırda çözülebileceğini göstermeye çalışacağız.
\end{abstract}

Anahtar Sözcükler: Film teorisi, Immanuel Kant, Gilles Deleuze, estetik, zaman

\footnotetext{
* Geliş tarihi: 26/11/2019 • Kabul tarihi: 02/02/2020

** İstanbul Arel Üniversitesi İletişim Fakültesi Yeni Medya ve İletişim Bölümü

Orcid no: 0000-0002-8377-513X, guvenozdoyran@arel.edu.tr
} 


\title{
Retrospective Re-readings in Media Studies: Kant and Film (After Deleuze)
}

\author{
Güven Özdoyran*
}

\begin{abstract}
In general, any attempt to explain what the film as a moving image is and/or what it comes to mean, arguments inevitably encounters with a deadlock that differs in two ways. In the first case, the film is confined to the cinematic apparatus that produces it technically. In this context, the film is conceived merely as the "mimetic-mechanical repetition" of the mechanism of human's mental perception and cannot overcome such a "mimetic relationship". In the second case centered on the audience, the film and the experience of watching a film is reduced to a "voyeuristic" relationship that almost points to a pathology. Gilles Deleuze, on the other hand, introduces a much more productive reading of the film, which completely excludes these two paradigms while constructing a new kind of film theory. Thus, we have an opportunity to answer the question of why we enjoy watching a film, in a non-negative way. Film as a moving image continues to infiltrate the minds as an enigmatic entity both in the context of the time in which it exists and in the time it produces itself. The main argument of this article is that Immanuel Kant's aesthetic theory can open up a new space for the reader in an effort to grasp the phenomenon of film and such a unique concept of time or temporality inherent in the film. The exclusive nature of Kant's aesthetic theory allows us to make a new and productive reading of the film and the concept of time that it produces, without limiting or reducing it. Another argument raised by the article is that Kant's conception of time which is immanent to his aesthetic theory cannot be located outside the time produced/contained in the film. In this way, we have another opportunity to answer the question of why we enjoy watching a film, in parallel with Deleuze, by excluding the mechanism that colonizes seeing or the gaze. Under the light of all these discussions, in this article, we will attempt to show that the "anomalies" that the previous explanation models for the film ignore can be solved at the boundary between Kant's epistemology and his aesthetic theory.
\end{abstract}

Keywords: Film Theory, Immanuel Kant, Gilles Deleuze, aesthetics, time.

\footnotetext{
${ }^{*}$ Received: 26/11/2019 - Accepted: 02/02/2020

** Istanbul Arel University Communication Faculty Department of New Media and Communication Orcid id: 0000-0002-8377-513X, guvenozdoyran@arel.edu.tr
} 


\section{Medya Çalışmalarında Geriye Dönük Yeniden Okumalar: (Deleuze Sonrası) Kant ve Film}

"Dünya ötede idi. Burada bir konsol, bir ayna, bir alçıdan gemici... soba, battaniye vardı. Dünya ötede idi."

S. F. Abasıyanık

"Fotoğraf" ile "hareketli görüntü olarak film"i algılamamız arasında ne tür bir farklılık vardır? Bir fotoğrafın ne anlama geldiğini, belki de en isabetli bir biçimde, Joseph Kosuth, Bir ve Üç Sandalye (1965) isimli yapıtıyla (üstelik bu yapıtın kendisini de bir fotoğrafta görürüz) aynı anda hem oldukça yalın hem de sofistike bir biçimde "hissettirir". Öte yandan, "hareketli görüntü” olarak "film” veya özel bir tür deneyim olarak "film ile karşılaşma" ne anlama gelir? Film ile kurduğumuz ilişki ne tür bir ilişkidir? Filmin "hareketli görüntü" olarak var olması bu ilişkiyi nasıl doğrudan etkiler? Gilles Deleuze bu soruların cevabını iki cilt halinde yayınladığı (Cinema 1: The MovementImage (2001a) [1983], Cinema 2: The Time-Image (2001b) [1985]) ve yeni bir tür sinema teorisi kurguladığı yapıtında kurduğu son derece yoğun ve grift argümanlarla göz alıcı bir biçimde tartışmaya açar. Bu noktada bir diğer soru, hali hazırda sinemayı teorize ve sistematize eden çabalar dururken Deleuze'ü sinemayı yeniden "okumaya" yönelten sebebin ne olduğu sorusu gündeme gelir. Deleuze bu sorunun yanıtını tartışmaya yer bırakmaksızın ikinci cildin sonunda verecektir. Onun açısından sinema, "yeni tür imgeler pratiği"dir ve sinemayı teorize etmeye yönelik psikanalitik veya dilbilimsel çabalar, teknik belirlenimler olarak, bu fenomeni açıklamakta yetersiz kalırlar (Deleuze, 2001b: 280). Deleuze'ün yükselttiği bu itiraz oldukça haklıdır. Psikanaliz bağlamında buradaki temel mesele, onun yalnızca "ana akım Hollywood sineması"nı gözeterek "film" deneyimini ele alması ve tümüyle "negatif" bir okumayla sinemayı "ideolojik bir aygıt” olarak mahkûm etmesidir. Örneğin Laura Mulvey (2008), son derece yoğun "teori-bağımlı" bir konumdan hareket ederek, sinematik aygıtı, ideolojik bir aygıta indirger. Psikanalizin kendi terminolojisini kullanarak söyleyecek olursak, bu açıklama modelinde psikanalizin dolduramayacağı "boşluk", "sanat olarak sinema" deneyiminde daha da derinleşir. Sinema perdesi ile "voyeristik/skopofilik ve özdeşleşme" ilişkisi dışında başka türden bir "ilişki” kurmamız bizzat teorinin kendisi tarafından neredeyse imkânsız hale getirilir. Dolayısıyla, psikanaliz açısından sinema 
deneyimi tümüyle "negatif" bir bağlama oturtulur ve film pratiğinin üretkenliği yadsınır. Ancak bir film yalnızca voyeristik bir biçimde "haz aldığımız" bir nesne midir? Bir "sanat deneyimi" olarak film izleme pratiğini "olumlu" olarak nasıl yapılandıracağız? Paul Wollen'in terminolojisiyle "sinefil" (cinephilia) kimdir? Psikanaliz açısından "sinefil" ("sinema deneyiminden alınan haz/keyif" anlamında), yalnızca negatif bir deneyime işaret ediyor gibi görünmektedir. Quid facti olarak "endüstriyel sinemadan nasıl keyif alıyorsak", aynı şekilde ve daha da fazla, quid facti olarak sanat sineması deneyiminden de keyif alırız. Deleuze'ün çabası ve bu makalenin amacı, bir yönüyle de, sanat sineması bağlamında quid juris olarak bu deneyimi olumsal bir zeminde temellendirme girişimidir.

\section{Kant ve Hareketli Görüntü Olarak Sinema}

Paradoksal görünse de bu makalenin tartışmaya açmak istediği ilk husus, psikanaliz ile Immanuel Kant'ın estetik teorisi arasında var olduğunu düşündüğümüz koşutluktur. Söz konusu koşutluk, Kant'ın estetik yaklaşımını film pratiğine uygulamamızı mümkün kılan olanak ile psikanalizi sinema deneyimini çözümlemede kullanışı bir araç kılan olanağın bir ve aynı olduğunun altını çizer. Dünyayı, nesneleri (ve dolayısıyla şeylerin deneyimini) kendileri olarak (thing-in-itself) değil, simgeler-semboller olarak kabul eden ve bu simgeleri "yorumlama" etkinliği olarak kendisini yapılandıran psikanaliz, söz konusu "yorumlama" kabiliyetini başka alanlara da yöneltir: Edebiyat, resim, medya ve kültürel çalışmalar vb. Dolayısıyla, psikanalizin sinema alanına uygulanmasıyla, onun bu türden "yorumlama" kapasitesine dayandığını söylemek mümkündür. Benzer şekilde, estetik ve sanat kuramını yapılandırdığı Üçüncü Eleştirisinde Kant, simge ve semboller üzerinden bir "yorumlama" uğraşına girer. Kant açısından "estetik ya da sanatsal deneyim" nihayetinde "epistemolojik" bir pratik değil, bir "yorumlama" işidir. Diğer yandan, Kant'ın psikanalizden farklılaştıran ve onu bu sapma hareketiyle tekrar Deleuze'e yakınlaştıran ana damar, onun estetik teorisinin merkezi teması olan "haz ya da keyif duygusunun" (ör. Kant, 1987: 191-192), psikanalizden tamamen farklı olarak, "sahte" bir tatmin veya yıkıcı bir deneyim değil, tam tersine üretkenliği, çoğulluğu, farklılıkları da içeren "yaşam duygusu”na karşılık gelmesidir. Haz 
duygusunun bizatihi kendisi üretkendir. ${ }^{1} \mathrm{Bu}$ anlamıla estetik deneyim ya da estetik haz, bir "eksikliğin"/"noksanlığın" manipülatif bir tatmini değil, "yaşam duygusunun" yeniden üretimidir. Dolayısıyla, bir filmden alınan haz ya da keyif istismar edilen bir durum değil, üretken bir edime dönüşecektir. Estetik ya da sanat söz konusu olduğunda, Kant açısından deneyimlediğimiz şey, Theodor W. Adorno'nun estetik kuramına referansla söyleyecek olursak, edimsel olanda ya da bilgi nesnesi olarak yaklaşılan, tahakküm kurulmuş haliyle dünyada içerilmeyen ancak var olan "daha fazlası"dır (the More) (Adorno, 2006). Sinema izleyiciye gündelik pratiklerinde temas edemediği bu türden gayri-nizami bir ontolojik gerçek olarak "daha fazla”yı gösterir. Böylece bu makalede, psikanaliz açısından bir anomali olarak kalan "sanat sineması deneyiminden neden keyif alırız?" sorunun olumlu yanıtının Kant'ın estetik kuramı ve epistemolojisi arasındaki "sınırda" bulunabileceği fikri tartışmaya açılacaktır.

Genel olarak bakıldığında ise, Kant'ın eleştirel felsefesinin, yine psikanalizle benzer şekilde, ama yaygınlık açısından ondan tümüyle ayrılarak (Kant'ı dâhil eden film çalışmaları nicelik olarak oldukça azdır), sinema alanında iki farklı izlek doğrultusunda araçsallaştırıldığını vurgulamak gerekir. Bunlardan ilkine göre, Kant'ın argümanları tek tek filmlerin içeriklerinin çözümlenmesinde/yorumlanmasında bir enstrüman olarak kullanılır. Örneğin, Slavoj Zizek, Lacan ile birlikte Kant'ın argümanlarını da film analizlerine dâhil eder. Daha doğru bir biçimde söyleyecek olursak, film analizi Zizek'in temel odağı değildir. Tersine, filmin kendisi ya da film analizi Zizek tarafından kendi yorumunu desteklemek için araçsallaştırılır. Filmler, bu anlamıyla, Zizek açısından, kendi teorisini destekleyen kanıtlar sunan "belgeler" olarak kullanıı. Örneğin Zizek, "Kantçı özne”yi film-noir sinemasının temsillerini izah etmek için temel referans noktası olarak kullanılır (Zizek, 2006: 84-116). Veya Catherine Wheatley, Haneke sinemasını doğrudan Kantçı etik ve "yüce" kavramlarını tartı̧̧masına dâhil ederek çözümler (Wheatley, 2009). Benzer şekilde Serdar Öztürk, Haneke'nin Amour (2012) filmi analizinde Kantçı etik özneye vurgu yapar (Öztürk, 2017: 54-56). Ayrıca Özgür Yaren, "Sinemasal Yüce: Felaket Filmlerinde Yüce Arayış”" başlıklı makalesinde, Kantçı "Yüce" kavramının sinemadaki örneklerini tartışmaya açar (Yaren, 2006).

1 Buradaki üretkenlik vurgusu, Kant'ın üçüncü Eleştirisi boyunca yürütmüş olduğu tartışmalara referansla yapmış olduğumuz yorumdur. 
Kant'ın içerildiği film çalışmalarının ikinci ayağında, Kant'ın eleştirel felsefesi, doğrudan mekanik bir aygıt olarak görülen "sinematik aygıt”ın kendisini açıklamak için kullanılır. Yukarıda vurguladığımız gibi, Kant'ın film çalışmalarına dâhil edilmesi yaygın bir strateji olmasa da ironik bir biçimde, tarihsel olarak bakıldığında film teorisini kurmaya yönelik erken dönem girişimlerin önde gelen isimlerinden biri olan Hugo Münsterberg, kendi film kuramını Kantçı paradigmayı merkeze alarak oluşturmaya çalışır. Fakat bu çaba yeterli olmaz ve ileriki yıllarda itibarını büyük oranda kaybeder. Öyle ki, 2000'li yıllarda film çalışmalarına tekrar sirayet eden "Kant'a dönüş" çabalarında Münsterberg'in ismi çoğunlukla zikredilmez. ${ }^{2}$ Kant'ın estetik kuramını takip ederek sinemada "Formalist/Biçimci" yaklaşımın ilk dönem temsilcisi olan Münsterberg, 1916 yılında yayınlanan The Photoplay: A Psychological Study adlı metninde, sinematik süreci, bütünüyle zihinsel süreçlere indirger ve "sinematik tüm nitelikler aslında zihinseldir" der (Andrew, 1976: 19). Bir başka ifadeyle, sinematik aygıt imge üretirken zihnin algıyı üretme süreçlerini taklit etmektedir. ${ }^{3} \mathrm{Bu}$ anlamıyla, nasıl ki müzik kulağın, resim gözün sanatı ise, sinemayı da "zihnin sanatı" olarak tanımlar (Andrew, 1976: 18). Öte yandan, zihnin ürettiği hareket algısı ve sinematik aygıtın ürettiği hareketli görüntü arasında, açıktır ki, bir fark vardır. Münsterberg açısından ilkinde üretilen hareket, uzamda gerçekleşen gerçek bir hareket iken, ikincisinde “ilişkilendirilmiş aksiyon fikri yoluyla hareketin farklı evrelerinin birleştirildiği 'zihnin içsel etkinliği' yoluyla üretilen hareketin etkisidir" (Sinnerbrink, 2014: 22). Münsterberg, Kant'ın epistemolojisine doğrudan referansla, insan zihninde içerilen "bellek" ve "imgelem" yetilerinin, hareketin sinematik yeniden-üretiminin ve düzenlenişinin doğal kaynakları olduğunu belirtir. Dolayısıyla sinemanın formu/biçimi yalnızca "zihinsel içerikleri, olayları" yansıtır. Sonuç olarak, bir film, Münsterberg açısından, dünyanın değil, ama zihnin kendisinin "medium"u olarak var olur (Andrew, 1976: 20). Lale Kabadayı'nın ifadesiyle, Münsterberg "photoplay" kavramını "filme kaydedilen oyun kelimesinden hareketle sinemaya karşılık gelecek şekilde kullanır ve fotoplay'in

\footnotetext{
2 Örneğin, Melinda Szaloky "Mutual Images: Reflections of Kant in Deleuze Transcendental Cinema of Time" (2010) ve Melissa Zinkin "Film and the Transcendental Imagination: Kant and Hitchcock's The Lady Vanishes" (2003) başlıklı makalelerinde film teorisini Kant'ı merkeze alarak yeniden yapılandırmaya çalışırken Münsterberg'i tartışmanın tümüyle dışında bırakırlar.

${ }^{3}$ Çok benzer şekilde, Bergson açısından da "film" ya da "sinematik aygıt", zihnin algılama sürecini taklit ederek "sinematografik yanılsama" yaratır. Deleuze, Bergson'un sinemayı bir "yanılsama" veya "taklit" olarak gören bu yaklaşımına itiraz eder. "Sinema bize hareketin kendisine sonradan eklendiği bir imge sunmaz. Aksine sinema, hareket-imgeyi dolaysız bir biçimde bize verir." (Deleuze, 2001a: 1-4).
} 
tamamıyla zihinsel hareketler tarafından şekillendiren dramatik olay örgülerini seyirciye gösterdiğini savunur” (Kabadayı, 2015: 101). Ancak, Münsterberg'in Kant merkezli oluşturduğu film teorisindeki en kritik hatalardan biri, Kant'ın kuramını “psikoloji”nin bir uzantısı olarak ele almasıdır. Adorno'nun da isabetle vurguladığı gibi, Kant'ın hem epistemolojik hem de estetik teorisi tümüyle "anti-psikolojik"tir (Adorno, 2006: 11-13 ve 170). Münsterberg'in ilki ile de bağlantılı ikinci hatası "zihin" ile “dünya"yı birbiriyle temas etmeyen iki ayrı ontolojik kategori olarak ele almasıdır. Kant'ın sadece epistemolojik teorisi göz önünde bulundurulduğunda bu ayrım anlamlı görünebilir. Fakat Kant'ın dünyayı ve yaşamı kendi tekillikleri içerisinde, üretkenliği ve çeşitliliği ile deneyimlemenin olanağını açan estetik ve sanat teorisi göz önünde bulundurulduğu zaman bu ayrım geçerliliğini büyük oranda kaybeder. Melissa Zinkin, Kant'ı tekrar film teorisine dâhil etme girişiminde, Kant'ın sanat-estetik kuramı üzerinden "bilişsel bir film teorisi" kuramayacağımız gerçeğinin altını çizer (Zinkin, 2003: 253-254). Dolayısıyla, hareketli görüntü olarak film, dünyayı yalnızca bir bilgi nesnesi olarak sunarsa bu ayrım Kant açısından "meşru" bir ayrımdır. Sanat açısından bakıldığında ise bu ayrım, bir filmin ne anlama geldiğini sorgularken çıkış yolu olarak değil, tersine bir engel olarak karşımıza çıkar. Tam da bu yüzden "bir film ile temasa geçtiğimizde neden keyif aldığımız" sorusunu yanıtlarken, filmin "amaçsız amaçlıığını" açıklama çabasında Münsterberg'in film kuramı kaçınılmaz olarak sessiz kalır. Kant teorisinde, estetik deneyimi ve haz duygusunu ele alırken hem yaşamdaki/doğadaki hem de estetik nesnelerin kendilerindeki "amaçsız amaçlılı̆ı" "simge/sembol" kavramları üzerinden tartışır. Buna göre, yaşamı bilgi nesnesi olarak değil ama "hissedilen" bir canlılık/üretkenlik/çeşitlilik olarak "analoji" yoluyla, yani "sembol/simgeler" yoluyla yorumlarız ve böylelikle estetik deneyimin kendisini ve "haz duygusu"nu anlamlandırmaya çalışırız (Kant, 1987: 342-361).

Estetik yargı, doğayı ya da yaşamı onu belirlemeksizin, yalnızca sanat ile analoji yoluyla değerlendirir (Kant, 1987: 464). ${ }^{4}$ Bu ilişkisel bir tanıma biçimidir ve bu yönüyle Kant açısından, yaşamı ve doğayı analojik tanıma/deneyimleme, şematize edilmiş

\footnotetext{
4 İngilizce literatürde genel kabul gören yaklaşım, Kant'ın İngilizceye çevrilen metinlerini hem birbirleri ile hem de orijinal Almancası ile karşılaştırma amaçlı, bu çevirilerde sayfa numarasına ek olarak Almanca orijinal baskılardaki paragraflara denk düşen paragraf numaraları ile vermek şeklindedir. Bu makalede de söz konusu yaklaşım benimsenmiş ve sayfa numarası yerine paragraf numaraları verilmiştir. Ek olarak, Critique of Pure Reason'a yapılan atıflarda "A" (Metnin Almanca ilk baskısı) ve "B" (ikinci baskısı) harfleri yer alır.
} 
bilişsel süreçten veya tanımadan tümüyle ayrılır. Yaşamı estetik açıdan deneyimlerken yargı gücü, deneyim nesnesini onu bir anlama yetisinin kavramı altında tahkim etmeden, onu belirleyip sınırlandırmadan analojik olarak anlamlandırmaya çalışır (Kant, 1987: 352-353). Tam da bu yüzden Kant açısından estetik deneyimde ortaya çıkan "haz duygusu" aynı zamanda "yaşam duygusu"dur (Kant, 1987: 204-220).

Münsterberg'in vurgu yaptığı "zihnin algılama süreci” ile sinematik aygıtın üretimi arasındaki paralellik, aslında, genel olarak kabul gören bir eğilime de işaret eder. Ancak, Kant'ın estetik teorisini içermeyen, yalnızca Kantçı epitemolojide duran bir açıklama girişimi, sinematik imgeyi "taklit etme yoluyla mekanik bir yeniden-üretim" olarak kavramaktan öteye gidemeyecektir. Öyle görünmektedir ki, Münsterberg kendi film teorisinde, Laura Mulvey'in ve erken dönem psikanalitik film teorisinin Lacancı psikanalizi merkeze alarak oluşturduğu sinema okumalarının içine düştükleri ihmali tekrar eder. Mulvey'e “içeriden yönelen” eleştirilerde, teorisini oluştururken Lacan'ın "imgesel" evresinde durduğu, "gerçek" kategorisini ihmal ettiği sıklıkla vurgulanır. ${ }^{5}$ Benzer şekilde Münsterberg, Kant'a referansla oluşturduğu biçimci film teorisinde, Kant'ın epistemolojisinde durur ve estetik teoriyi anlatısının tümüyle dışında bırakır. Bu makalede, film teorisi bağlamında Kant'ı yeniden okuyarak ve onu Deleuze'ün sinema teorisi ile ilişkilendirerek, sıkışmış olduğu formel-mekanik yorumlarının dışına çıkarmaya çalışılacaktır. Hareketli görüntü olarak "film" fenomeni burada Kant'ın estetik teorisinin "açıklayıcısı” olarak işlev görmeyecektir, ya da karşıt biçimde, Kant'ın teorisi "film" fenomenini açıklamak için araçsallaştırılmayacaktır. Çünkü bu türden çabalarda, kaçınılmaz olarak film, Kant'ın estetik teorisinin "dışında konumlanan bir araştırma nesnesi” olarak kavranır. Burada ise, hareketli görüntü olarak düşünceimgesi üreten "film" pratiğinin bizatihi kendisinin Kant'ın estetik teorisinin "içinden" konuştuğu, bu teorinin "gerçekleşmesinin imkânı" olarak da kavranabileceği gösterilmeye çalışılacaktır. Dolayısıyla, burada önerilen haliyle Kant'ın estetik kuramının film kuramı tartışmalarına dâhil edilmesi, eski olanı muteber kılan nostaljik bir restorasyon değil, tam tersi bir biçimde Kant'ın kendi teorisini de dönüştüren, onun çıkmazlarına çözüm üreten bir yeniden okumaya yöneliktir.

5 “içeriden yönelen" bu eleştirilere örnek: Copjec, 1994: 15-38. McGowan \& Kunkle, 2014: 9-20. McGowan, 2012: 17-24. 


\section{Kant'ın Evreni, Deleuze ve Film}

Makalenin sınırlı alanını da gözeterek özetleyecek olursak, Batı düşünce tarihinin en karanlık metinlerinin bir bölümünün üreticisi konumunda olan Kant, yazdığı üç temel metin ile (Saf Aklın Eleştirisi, Pratik Aklın Eleştirisi, Yargı Gücünün Eleştirisı) ${ }^{6}$ kendi "eleştirel felsefesini" tutarlı ve istikrarlı bir bütün haline getirmeye çalışır. Kant, Saf Aklın Eleştirisinnde epistemolojiyi, bilginin kaynağı ve sınırları sorununu ele alırken, ikinci Eleştirisinnde "ahlak/etik" tartışmasına, üçüncü Eleştirisinnde ise estetik/sanat kuramına ve organik doğanın teleolojisine odaklanır. Böylelikle, birinci Eleştiri'de "neyi bilebiliriz?" sorusunun cevabını vermeye çalışırken, ikinci Eleştiri'de "nasıl davranmalıyız?" sorusunu ve üçüncü Eleştir’de ise "neyi umabiliriz?" sorusuna cevap vermeye çalışır. Buradaki kronolojik sıra aslında sistematik olarak kendisini dayatır: Kant açısından üçüncü Eleştiri’nin amacı, ilk iki proje arasında oluşan boşluğu kapamak, ikisi arasında tutarlı bir bağlantı kurmak ve temas ettirmektir. Dolayısıyla, "yargı yetisi" (İng. Judgment, Alm. Urteilskraft), "anlama yetisi" (İng. Understanding, Alm. Verstand) ile "akıl" (İng. Reason, Alm. Vernunft) arasında oluşan boşluğu doldurma işlevini yerine getirir. Burada sorunlu görünen olan taraf, Kant'ın estetik/sanat teorisini de insanın "bilişsel kapasiteleri" ile açıklama girişimidir. Bir başka ifadeyle, Kant'ın hem epistemolojisinde hem de estetik teorisinde kullandığı enstrümanlar aynıdır fakat bu enstrümanların fonksiyonları farklıdır. Kant'ın kurduğu evrene bir meta-bakış ile göz atacak olursak şunu fark ederiz: Aslında hem epistemolojik öznenin, hem ahlaki öznenin hem de estetik deneyim yaşayan öznenin var olduğu dünya bir ve aynı dünyadır, aynı şekilde üzerine konuşulan epistemolojik özne, etik özne ve estetik özne de bir ve aynı öznedir. Ancak sorun, birbirinden son derece girift bir biçimde ayrıştırdığı bu üç konumu tekrar birbiriyle tutarlı bir biçimde birleştirme meselesidir.

Kant ilk defa, üçüncü Eleştirisinnde dünyadaki çeşitlilikten, çoğulluktan, canlılıktan ve yaşamdan yola çıkar ve evrensel/tümel bir birliğe indirgemeksizin bilişsel bir manevrayla tekrar bu çoğulluğa varır. Böylelikle, Kant'ın çalışmalarında yaşamda içerilen "farklar" ve dolayısı ile "tekillik halleri" ilk kez görünür olur. Benzer şekilde yine ilk defa üçüncü Eleştirisinnde tikel öznelerin çoğulluğunu, organikliğini ve canılıı̆ını,

\footnotetext{
${ }^{6}$ Alm. Kritik der reinen Vernunft (1781) (Bu makaledeki referans metin: 1965), Kritik der praktischen Vernunft (1788), Kritik der Urteilskraft (1790) (Bu makaledeki referans metin: 1987).
} 
bilişsel kapasitenin evrensel yasalarına indirgemeden saptar ve bu saptamayı tartışmanın sonuna taşır. Tam da bu yüzden Kant “iletişim” kavramını ve bu kavramın zorunlu olarak varsaydığı "öznelerarasılık” nosyonunu merkeze alarak estetik teorisine dâhil eder.

Saf Aklın Eleştirisi ile birlikte, Kant açısından "bilgi", nesnenin tümüyle kendisine ait ve öznenin pasif bir biçimde alımladığı verili bir gerçek olmaktan çıkar ve öznenin bilişsel kapasiteleri ile nesne arasında özel bir tür ilişki/süreç sonucu üretilen bir yapıya dönüşür. Dolayısıyla Kant açısından "bilgi” daima "koşullu” olmak durumundadır. İlk Eleştirınin "Analitik" (1965: A 66 - B 91) bölümünde Kant, doğa yasalarının (bilimsel bilginin) nesnel geçerliliğini de sağlayan bilginin bu koşullarını saptar. Söz konusu yapılandırma süreci aynı zamanda deneyimin sınırlarını da tümüyle belirler ve bu sınırların her türlü ihlali Kant tarafından "dogmatik metafizik" olarak değerlendirilip mahkûm edilir (Kant, 1965: A ix-A x). Bu koşulu gerçekleştirmek üzere Kant, -kendisi bunu "Kopernik Devrimi" olarak adlandırır-, ${ }^{7}$ epistemolojik alanda radikal bir hamle yaparak, (bilinen) nesne ile (bilen) özne arasındaki ilişkiyi kesintiye uğratarak tersine çevirir. Böylelikle, "özne" merkezi ve aktif (bilme ediminde artık pasif bir alıcı konumunda çıkar) bir role kavuşur. Crary, Kant'ın “Kopernik Devrimi” ile birlikte, görme ediminde "öznenin yeniden örgütlendiği ve konumlandırıldığı”nı, bunun sonucu olarak görmenin de artık "ayrıcalıklı bir bilgi biçiminden çok, bilginin ve gözlemin nesnesi” haline geldiğinin altını çizer (Crary, 2015: 83-84). Ancak bunun bir bedeli olacaktır. Artık nesneler oldukları gibi bilinemez durumdadır, dünyanın ve nesnelerin ontolojik anlamı gündemden tamamıyla düşer. Bir başka ifadeyle, dünya artık öznenin her zaman için ötesinde konumlanır: Phenomenon ve Noumenon ayrımı. Bunun bir başka sonucu da dış dünyayı "dolayımsız" (koşulsuz) olarak bilmenin imkânsızlığıdır. Sinemayı bir "temsiller sistemi" olarak, yani "dolayım" olarak görmenin ve onu itibarsızlaştırmanın önemsizleştiği Kantçı bir vurgudur bu. Çünkü en dolayımsız haliyle bile, dış dünyayı algılamamız zihnimizin ürettiği "temsiller" dolayımı ile gerçekleşmek zorundadır. Kant dış dünyayı "bilinç içerikleri”ne çevirerek onu "kesin” bir biçimde bilebileceğimize yönelik bir argümanlar bütünü sunar. Kantçı epistemolojik evrende, zihinsel içerikler, imgelerimiz ve dünyaya dair tüm algı içeriklerimiz birer "temsil"e

\footnotetext{
7 Rodowick, Deleuze'ün sinema teorisine yönelik ters-yüz etme girişimini "Kantçı Kopernik devrimine" benzetir (Rodowick, 1997: 83).
} 
dönüşür. O halde, epistemolojik olarak öznenin gerçeklik deneyimi ile film arasında ilki lehine üretilen ontolojik farkın ortadan kalktığı böylesi bir durumda, sinema "öznenin deneyiminden" çok daha avantajlı bir konuma ulaşır. Çünkü Dziga Vertov'un kavramsallaştırması ile "sine-göz", "beden bağımlı konum olarak var olan göz"ü bu sınırlılıktan (bedenden) kurtarır ve onu özgürleştirir. Bedensel olarak her zaman için “ötede olan dünyayı” ya da bedenin her zaman "ötesinde olan dünyayı” çoğullaştırarak bedene geri taşır.

Kant'ın argümanlarını film teorisi bağlamına oturtmaya imkân tanıyan bir diğer vurgu ise, Kant'ın kendi sisteminde "imgelem" ve "zaman" kavramına sağladığı ayrıcalıklı konumlardır. "İmgelem yetisi”, Kantçı evrende "zaman”ı yalnızca düzenleyen değil ama aynı zamanda (ve oldukça tartışmalı bir biçimde) üreten ve nesneleri zamansal konumlarına göre düzenleyen, metaforik olarak söyleyecek olursak hem bir kamera hem de montaj cihazı işlevi görür. Dahası, Kant'ın sisteminde "zaman", "uzam"da ve "hareketin" kendisinde içerilen, dış dünyaya ait bir kavram olmaktan bütünüyle çıkar. Birinci Eleştirinin "Aşkınsal Estetik” bölümünde Kant, "zaman” ve "uzam"ın özneye ait a priori duyu formları olduğu fikrini tartışmaya açarak onaylar. Onun açısından zaman, deneyimden türetilen ampirik bir kavram değildir (Kant, 1965: B 46). Tam tersine, öznelik konumunda algılamayı ve deneyimi mümkün kılan şey, zihnin saf bir formu olarak zamandır. Deleuze, Kant'ın bu stratejik hamlesinin sonucu olarak zamanın, artık "ölçtüğü hareketten” bağımsız olarak var olduğunu, hatta hareketin kendisinin koşulu olan zamana bağıntılanmış olduğunu vurgular (Deleuze, 1995: 25). Daha da önemlisi, yine Deleuze tarafından, Kant'ın "zaman”ı ters-yüz edişi, sinemanın başarmış olduğu sapmanın bir başka biçimi olarak kabul görür (Deleuze, 2001b: 39-40).

Kant açısından, "dünya" ancak deneyimin birliği olarak vardır. Bu epistemolojik eşitleme, "deneyimin birliğinin nasıl mümkün olduğu" sorusu ile "deneyimin kendisinin nasıl mümkün olduğu" sorusunun bir ve aynı olduğuna işaret eder. Bir başka ifadeyle, Kant'ın sisteminde nasıl ki bilgi verili değil, üretilen bir yapı olarak mümkün ise, aynı şekilde deneyim de inşa edilen bir yapı olarak mümkün hale gelir. Kant öznenin bilme sürecini açıklarken aynı zamanda deneyimi ya da deneyimin birliğini mümkün kılan koşulları da göstermiş olur. Aynı şekilde, nesneler mümkün deneyimin nesneleri olabilmek için, öznenin duyu formlarına ve anlama yetisinin 
kavramlarına/kategorilerine uymak ve onlara tabi olmak (onlar tarafından belirlenmek) zorundadırlar. Bu türden bir “Kopernik Devrimi”nin zorunlu ve mantıksal sonucu olarak, doğa yasaları, anlama yetisinin doğaya empoze ettiği yasalardan başka bir şey olamazlar. Böylece, anlama yetisinin sınırları, dünyanın ve deneyimin de sınırlarına dönüşür. Görüleceği üzere, Kant'ın epistemolojisinde, farklı yetilerin bilme sürecine dâhil edilmesiyle, dış dünyaya yönelik bilgimiz neredeyse bir "montaj” olarak ortaya çıkar, ancak bu imgelemin, anlama yetisinin sınırlandırıcı ve belirleyici kavramları altında yaptığı/uyguladığı evrensel bir montajdır. Bir başka açıdan değerlendirecek olursak, Kant'a göre öznenin bilişsel yetileri, dış dünyadaki duyu verilerini tıpkı bir kamera gibi zamansal olarak ardışık bir biçimde alımlar ve bu dağınık çoğul verileri anlama yetisinin kavramları yoluyla anlamlı bir bütün haline gelecek şekilde montajlar. Örneğin, imgelem yetisinin de son derece kritik bir işlevi olduğu "nedensellik" (yasası) dış dünyada nesnelere ait bir kavram değil, tersine öznenin anlama yetisinin bir kategorisidir. Nesneler insan zihninin bu kategorisine tabi oldukları, onun tarafından belirlendikleri sürece bilinebilir olurlar. Deleuze'ün vurgusuyla, "anlama yetisi” dış dünyayı soyutlayarak ona kendi yasalarını dikte etmektedir (Deleuze, 1995: 53). Böylelikle Kant, "düşüncenin sübjektif koşullarının" "nesnel ve evrensel bir geçerliliğe" sahip olduğunu iddia eder (Kant, 1965: A 90). Burada vurgulanması gereken önemli hususlardan bir tanesi, bilme ediminde "imgelem yetisi”nin "anlama yetisi”ne tabi olduğu, onun kavramları/kategorileri yoluyla "sentez" yapabildiğidir. Bir başka ifadeyle, algının "aşkınsal formları" olarak "zaman" ve "uzam", duyu verilerini ham bir materyal olarak alımlarken, anlama yetisi ve imgelem bu ham veri çoğulluğunu işler ve anlamlı bir bütün haline getirir. Yukarıda vurguladığımız gibi, "a priori duyu formu" olarak "zaman" kavramı da Kant'ın eleştirel felsefesinden dış dünyaya ya da nesnelere ait bir belirlenim olmaktan çıkar ve öznenin bilişsel kapasitesinin bir parçasına dönüşür. Aşkınsal ya da a priori algı formu olmasının anlamı da deneyime önsel, onun koşulu olmasından dolayıdır. Ancak bu şekilde, zamansal olarak ardışık sıra ile meydana gelen iki olay arasında nedensel bir bağıntıyı nesnel ve evrensel olarak yapılandırabiliriz. Böylece imgelem yetisi, zaman ve uzam dolayımı ile elde edilen içerikleri sentezleyerek, şematize ederek, "temsiller" üretir. Yani, imgelem yetisi, dış dünyaya ait çoklu algı içeriklerini, anlama yetisinin kategorileri altında birleştirerek anlamlı/bilinebilir bir bütün haline getirir. Kant burada, imgelem yetisinin tesadüfi veya 
özgür bir biçimde çalışmadığını, anlama yetisi tarafından yönlendirildiğini ve bu yolla sistematik ancak sınırlı bir biçimde temsiller ürettiğinin altını çizer.

İnsanın zihinsel yetilerinin dünyayı ve nesneleri belirlemesine, anlama yetisinin kendi yasalarını dünyaya empoze etmesine, imgelemin "zamanın düzenini/sıralamasını" "ardışıklık" biçiminde "evrensel bir montaj” olarak ürettiğine yönelik en belirgin örnek "nedensellik yasası"dır. Kant, "Iikinci Analoji” (Kant "zaman”ın imgelem yoluyla düzenlenen üç durumunu -devamlılık, ardışıklık ve eşzamanlılık- üç ayrı Analoji başlığı altında tartışır) bölümünde "nedensellik yasasını" ele alır. Burada zamansal ardışıklığın üretilmesini nedensel ilişki ile tanımlarken kritik bir hamle yapar ve "nesne" ile "olay"ı birbirinden kesin bir biçimde ayırır. Kant'ın bu hamlesi sinematik aygıtın neyi başardığını görmemiz açısından da son derece önemlidir. Buna göre, Kant açısından imgelem, zaman, sentez ve şema bağlamında bir nesne ile olayın algılanışı radikal bir biçimde farklıdır. Kant, bir olayın gözlemlenişini, "algıların birbirini takip ettiği ardışıklık" olarak tanımlar (Kant, 1965: A 192). Olay ile nesnenin algılanması arasında yaptığı bu ayrım ile Kant'ın asıl amacı, "subjektif zamansal ardışıklık" ile "objektif zamansal ardışıklık" arasındaki farkı gösterebilmektir. Bu noktayı açıklayabilmek için Kant ev ve gemi örneğini verir. Ev örneğinde, nesnenin gözlemlenmesi ardışıktır. Buna göre, bir eve bakarken algım girişten çatıya doğru ya da çatıdan girişe doğru gerçekleşebilir. Algının istikametini tayin eden zorunlu bir parametre yoktur. Bir başka ifadeyle, burada gözlemimi belirleyecek zamansal ardışıklığın sırası zorunlu değildir ve temsillerin sırası keyfi bir biçimde belirlenir (Kant, 1965: A 192, A 193, B 238). Yani, zamansal ardışıklık nesnenin kendisine değil, özneye bağlıdır. Gemi örneğinde ise, zamansal ardışıklık zorunlu ve dolayısıyla evrensel ve objektiftir. Bir nehirde yol alan gemiye baktığımızda ilk olarak gemiyi A noktasında daha sonra ise B noktasında gözlemleriz. Bu olayda temsillerin oluşturulmasındaki zamansal sıra gözlemciye değil, olayın kendisine göre belirlenir. A noktası ile B noktası arasındaki sıralama zorunlu ve objektiftir (Kant, 1965: A 198). Burada imgelem, sentez yoluyla temsilleri şematize ederken zamanın ardışık olma ilkesine göre sentezler. Kant "görüngüler zamanda ardışık bir biçimde konumlanmalarına göre belirlenir" (Kant, 1965: A 200) diye belirtir. Algının ve temsillerin zamansal düzenlenişi ve sırası imgelem ve anlama yetisinin kavramları tarafından zorunlu, nesnel ve evrensel bir biçimde üretilir. Böylelikle, makalenin girişinde verdiğimiz örneğe geri dönerek söyleyecek olursak, örneğin bir 
"fotoğraf"ı algılamak ile hareketli görüntü olarak bir filmi deneyimlemek iki ayrı düzeneğe işaret eder. O halde sinemanın yaratmış olduğu imkâna referansla söylendiğinde, sinemanın kamera, çekim ve montaj yoluyla başardığı şey, "olay"ın kendisini ve olayı zorunlu ve nesnel bir ardışıklık ile düzenleyen "zaman"ı bu "zorunluluk" yükünden kurtarması ve onu tekrar subjektifleştirmesi ve özgürleştirmesidir -Deleuze bu noktayı Hareket-Imge kitabında dekupajı Alfred Hitchcock sinemasını dâhil ederek tartışırken gündeme getirir- (Deleuze, 2001a: 1920). Sinemanın yarattığı olanak, algıyı, mekanik kayıt ve montaj yoluyla, imgelem ve anlama yetisinin tahakküm kurucu etkisinden kurtarıp onu yeniden üretme/düzenleme, dünyayı başka türlü gösterme imkânıdır. Deneyimin aksine, sinemadaki kurgu veya montaj zorunlu değil keyfidir, serbest bir biçimde "olaylar" zamansal olarak yeniden düzenlenir. Deleuzeyen vurgu ile formüle edildiğinde, epistemolojik algılamada parçalar arasındaki ilişki (örneğin Kant anlama yetisinin belirleyici kavramı olarak "nedensellik"i ilişki bağlamında tartışır) homojen iken, filmde hareketli görüntü kurgulanırken bu ilişki heterojenleşir. Filmde, algının bağımsızlaşmasıyla benzer şekilde, parçaların birbirleriyle ilişkileri de rizomatiktir.

Özetle, yukarıda Münsterberg bağlamında da vurguladığımız gibi, sinematik aygıtı Kantçı epistemolojiye yaklaştıran koşul, "beden bağımlı konum olarak göz" ile mekanik göz olarak kamera" ve "montaj” arasındaki bu türden koşutluktur. Kant'ın epistemoloji bağlamında "filme çektiği" haliyle dünyayı algılamamızı sağlayan rutinmekanik düzenek, sinematik aygıt ile paralellik taşır. Hareketli görüntü olarak film ve montaj, nasıl zamanı ve uzamı düzenliyor ise, aynı şekilde, Kant'ın epistemolojik düzeneğinde, imgelem zamanı ve uzamı düzenler ve sıralar. Claire Colebrook, bu imkânı yaratan sinemayı "imgeleri sabit bir bakış açısından özgürleştirme gücü veya potansiyeli” olarak tanımlar (Colebrook, 2004: 55). "Yalnızca sinema aracılığıyla insan gözüyle kısıtlı olmayan bir görme tarzı düşünebiliriz" (Colebrook, 2004: 44-45). Dolayısıyla, yukarıda vurgulanan haliyle, kamera yoluyla "beden bağımlı konum olarak göz"den ayrışarak bağımsızlaşan, göçebeleşen algı, böylelikle yertsizyurtsuzlaşır. Ancak yersizyurtsuzlaşan yalnızca algı değildir. Maurizio Lazzarato, "sinemayla birlikte, algı, görme ve düşünce mutasyonları haline geldiğimize" vurgu yapar. "Bedenlerin oluşunda, yersizyurtsuzlaşmış bir dünyanın virtüeliğini yakalayan sinema, yeni bir bedene ve yeni bir düşünceye doğru açılır” (Lazzarato, 2016: 223). 
Lazzarato'nun bu alıntısını, Deleuze'ün (Pier Paolo Pasolini ve Michail Bakhtin bağlamında sinemanın linguistik yoluyla kavranmasına itiraz ederken) John Dos Passos'a referans vererek yapmış olduğu "anonimlik" vurgusu ile beraber düşündüğümüzde, "kameranın gözü” yoluyla algının ya da görmenin "anonimleştiğini”" de (Deleuze, 2001a: 72-73) söyleyebiliriz ve böylece film izleme pratiğinde bu algının deneyimi de anonimleşir. Colebrook'un ifadesiyle, sinema nihayetinde "görmenin görülmesidir", filmde "görmeyi görürüz" (Colebrook, 2004: 49). Hareket-Imgesi ve Zaman-imgesi metni boyunca "anonim" kavramını olumsuz anlamda kullanan Deleuze'ün burada saptadığı olumsallığı, anonimleşme yoluyla "deneyimin virtüel olarak çoğullaşması" olarak okumak mümkün görünüyor. İlgili bölümde Deleuze kritik bir şerh düşerek, film pratiğinde sübjektif olarak üretilen algının, "objektifleştiğine/nesnelleştiğine" yönelik "teorilere" itiraz eder. Bu son derece anlaşılır bir itirazdır, çünkü algının anonimleşmesi, onun tüm özneler tarafından "evrensel, nesnel ve zorunlu” biçimde, aynı şekilde "görülmeleri” sonucunu çıkarmaz. Berger'in “fotografik imge"yi tartışırken ortaya koyduğu argümana (Berger, 2005) referansla söyleyecek olursak, sinematik aygıt ile oluşturulan hareketli görüntü "tek bir anlama gelmez", tekil bilinçle her karşılaşmasında anlamı yeniden üretilir, çoğullaşır. O halde, film, algıyı ve görmeyi anonimleştirerek dünyayı, dünyanın deneyimini ya da deneyimin kendisini de virtüel olarak yersizyurtsuzlaştırır.

Öte yandan, Deleuze bağlamında söyleyecek olursak, yalnızca erken dönem sinemanın belirleyici niteliği olan ve "anlatı sineması"nın temelini oluşturan "hareketimgesi”, Kantçı epistemolojik algı pratiğine benzer üretim yapar. "Zaman”ı harekete indirgeyerek/hapsederek onun ancak dolaylı bir temsilini sunan montaj, Deleuze açısından, zamanın dolaylı temsilidir, hareket-imgesi sinema pratiğinin otomatik (Deleuze, 2001a: ix) ve teknik (dolayısıyla zorunlu) bir sonucudur. Anlatı sinemasında, Deleuze'ün "duyusal-motor şeması" olarak tarif ettiği (Kantçı terminolojideki şema ile benzerliği oldukça açıktır) düzenek ve "sinemanın ilkesel edimi olarak" montaj (Deleuze, 2001b: 34), hareketi ve "zamanın akışını", Kantçı epistemolojik sürece çok benzer şekilde, yeniden üretir ve olayları mantıksal bir sıralama ile yeniden düzenler (Deleuze, 2001b: 272). Ancak bu filmi anlatan hikâyenin yalnızca bir kısmıdır. Diğer kısmına yönelik Deleuze'ün uyarısı metnin tamamına nüfuz eder. Sinematik aygıtın otomatik olarak ürettiği ve duyusal-motor bağlantılar yoluyla birbirine mantıksal bir sıra 
ile ilişkilendirilerek oluşturulan anlatı sineması bu haliyle, sıradan algının ürettiği "alışkanlıkları" ve dolayısıyla klişeleri ve banalliği yeniden üretme riskini yalnızca taşımaz onu gerçekleştirir de. Deleuze, sinemada klişeyi (hareket-imgesinin üç formundan biri olan) "aksiyon-imgesi"nin "krizi" olarak saptar (Deleuze, 2001b: 4) ve klişeyi "nesnelerin/şeylerin duyusal-motor imgesi” olarak tanımlar (Deleuze, 2001b: 20). Devamında ise hem kendi film teorisi hem de bu makalenin sorunu bağlamında son derece kritik bir tartışmaya girişir:

Klişe, bir şeyin duyusal-motor imgesidir. Bergson'un dediği gibi, bir şeyi veya imgeyi bütünüyle -kendi bütünlüğü içinde- değil, aksine her zaman onun olduğundan daha azını algılıyoruz. Yalnızca ilgilendiğimiz şeyleri, ekonomik çıkarlarımız, ideolojik inançlarımız veya psikolojik ihtiyaçlarımızın yönlendirdiği ilgimiz doğrultusunda algılıyoruz. Bu nedenle normalde sadece klişeleri algılarız. Duyusal-motor şemalarımız sıkışırsa veya çökerse, ancak o zaman farklı bir imge ortaya çıkabilir: Saf bir optik-ses imge (Deleuze, 2001b: 20).

Deleuze, burada, endüstriyel sinema ile sanat sineması arasına belirgin bir mesafe koyar. Onun açısından, "iyi” filmi, kötü filmden ayıran temel parametreler banallik, klişe ve standartlaşmadır. Ancak Henri Bergson'u tartışmasının merkezine -tekrartaşıyarak rutin-gündelik algı ile sinematografik imgenin klişeliği arasında doğrudan bir ilişki kurar. Bildiğimiz üzere Bergson, "akıl" (intellect) ile "sezgi"yi (intuition) veya "matematikselleştirilmiş mekanik dünya" (bilgi nesnesine indirgenmiş haliyle, bilinebilir "dünya") ile "yaşam"ı iki farklı ontolojik konum olarak birbirinden radikal bir biçimde ayırır. Bu ayrımın izdüşümü olarak "zaman" kavrımını da "süre" (durée) ve "matematikselleştirilmiş, uzama tabi kılınmış zaman" olmak üzere tasnif eder. Bergson açısında, yaşam ya da "şey"ler, bilimin iddiasının aksine, sürekli ve kesintisiz bir "oluş" halindedir. Ancak uzamsallaştırılmış ve matematikselleştirilmiş (matematiksel olarak ölçülebilir olan) "zaman", kendisini, yaşamı ve kendi içerisinde konumlandığını varsaydığı "şey"leri homojen "ardışıklıklar" olarak yapılandırır. Kesintiler yoluyla oluşturulan bu ardışık zaman, asında, bilimin ve zihnimizin/algımızın mekanik işleyişinin doğal bir sonucu olarak "üretilmiştir". Bergson, dünyanın ve şeylerin bu şekilde matematize edilerek, "akış"tan ve "oluş"tan kopartılarak anlama çabasının bizatihi kendisini "yanılsama" olarak tanımlar. Bergson, "fotografik imge" ve "sinematografik imge"yi bu türden bir "yanılsama"yı ve matematikselleştirilmiş- 
uzamsallaştırılmış pseudo-zaman'ı örneklendirmek için kullanır. Birbirine dışsal zamansal birimler olarak "geçmiş", "şimdi” ve "gelecek", enstantane fotoğraflar gibi birbirinden kopartılır, sabitlenir ve hareketli görüntü olarak sinemada bu tek tek fotoğrafların ardışık olarak sıralanması yoluyla "zaman ve hareket” yapay bir biçimde yeniden üretilir. Bu anlamıyla, sinemanın gösterdiği "hareket" ve "zaman" da üretilmiş bir "yanılsama"dır. Yukarıdaki Kant'ın epistemolojisi bağlamında yürütmüş olduğumuz tartışmayı da göz önününde bulundurarak vurgulayacak olursak, Bergson açısından zihnimizin/algımızın bizatihi kendisi "sinematografiktir" (Bergson, 1998: 347). Sinema, zaten algımızın kendi doğası gereği sahip olduğu bu türden mekanik işleyişini taklit ederek hareketi üretir. Öte yandan, yaşamın ve şeylerin gerçek/mutlak varoluş biçimleri, sinematografik ve sıradan algımızın kavrayışının tümüyle dışında, yalnızca "süre" içerisinde kesintisiz bir akış ve oluş olarak değişim/hareket içerisindedir. Deleuze'den yapmış olduğumuz alıntıyı, Bergson'un burada yürütmüş olduğu tartışma ile birlikte düşündüğümüzde, rutinleşmiş, sıradan (edimsel) algımız naturası gereği gerçeği ıskalar ve dünyayı homojen bir yapı olarak tasnif edip kavramaya çalışır. Her algı, bu anlamıyla, algıladığı şey üzerinde tahakküm kurar ve onu kolonileştirir. Tam da bu yüzden, tahakküm aracı olarak rutin algı, kendi görme biçimini "nihai" kabul ederek mutlaklaştııır/normlaştırır. Bir alışkanlıklar bütününe dönüşerek, yaşamın üretkenliğini, canlılığını, içerdiği farklılıkları homojenleştirir, sıradanlaştırır ve bilebileceği biçime indirger. Bir başka ifadeyle, edimsel algı kendi rutini içerisinde bilinmeyeni ancak daha önceden bildiği bir şeye indirgeyerek, ona benzeterek anlamlandırır ve tasnif eder. Bu noktada, Deleuze'ün gündelik algı ile anlatı sinemasının ve aksiyon-imgesinin ürettiği klişeleri arasında öngördüğü bağıntıyı gözlemleyebiliriz.

Sinemanın "meta-formu" olarak ticari-ana akım sinema da benzer şekilde, görmeyi tekrar standardize ederek, klişeleri, banalliği üretir. Kendi görme rejimini merkezileştirerek/norm haline getirerek görmenin çoğulluğunu homojenleştirir/tekleştirir. Böylelikle, izleyicinin algısı özdeşleşme ilişkisi dolayımıyla tahakküm altına alınır: İzleyicinin bakışı, kameranın "klişe ve banal” bakışı tarafından asimile edilerek ve sömürgeleştirilir. Bu haliyle ticari sinema, anlatıyı oluştururken imgelerin sıralanışını standardize ederek monotonlaştırır ve "alışkanlığı" yeniden üretir. Göstergenin bizatihi kendisinin metalaştığı ve sıradanlaştığı ticari sinema pratiği, 
Louis Althusser'in ideoloji bağlamında teorize ettiği haliyle "öznenin çağırılışı" (Althusser, 2006: 96-103) jestini "sinematik çağırılış"a tercüme ederek özneleri anonimleştirir. Deleuze'ün "anonim” kavramını negatif kullanımı burada, sinematik aygıtın klişeleşmiş imgeler ürettiği bu uğrakta gündeme gelir ve tekrar edilir. Sinematik aygıtın kendisine içkin üretken doğasına ragmen böylesi bir "standartlaşmayı" enfekte edebilmesini, Deleuze'ün Kapitalizm ve Şizofreni (1999) metnini başka bir bağlamda yürüttüğü tartışma ile beraber okuduğumuzda anlamlı hale getirebiliriz. Buna göre, kapitalizmden önce merkantilistlerde zenginliğin özü, sabit, değişmez ve monumental bir objektite bağlanmıştı. Daha sonra, bu türden bir sabit ortadan kalktı ve (Deleuze buna "Kantçı geri dönüş" diyor) öznenin kendisine iliştirildi. Ancak bu değişimin sonucu olarak öznenin kendisi de değişime uğradı ve kapitalist üretim ilişkileri yoluyla belirlenerek bir başka ve daha büyük bir sabit merkeze dönüştü (Deleuze, 1999: 7375). Tıpkı buradaki çift yönlü ilişki gibi, sinema aygıtı önceleri deneyimi ve bakışı çoğullaştıran bir üretim iken, daha sonra kapitalist üretim ilişkilerine dâhil olarak kendisi de dönüştü ve "standartlar, klişeler" üreten bir aygıt halini aldı.

Buraya kadar sinematik aygıt ile Kantçı epistemelojik algılama arasındaki ilişkiyi göstermeye çalıştık. Öte yandan, iki Eleştiri’yi kıyaslayarak yorumlayarak söyleyecek olursak, Kant açısından, dış dünyaya ait deneyimimiz yalnızca epistemolojik değildir, bir başka ifadeyle, nesne ile kurduğumuz ilişki biçimi sadece bilme kapasitesi üzerinden tanımlanamaz. Dünya bizim için yalnızca bilimsel belirlenimciliğin araştırma nesnesi değildir, dünyayı deneyimlerken aynı zamanda bir şeyler "hissederiz". Estetik deneyim, duyusal bir içerikten alınan haz, bu türden bir epistemolojik belirlenim ilişkisinin dışında konumlanır. Bu yönüyle, örneğin, film izleme deneyimi, izleyici açısından bir bilgi edinme performansı değildir. Kant, üçüncü Eleştirisi'nde bu türden estetik deneyimi ve "haz" duygusunu ele alır. Şunu vurgulamaya çalışıyoruz: İki yargı tipi, "Su, 100 derecede kaynar" yargısı ile "Stalker iyi bir filmdir" yargısı, aynı dili konuşmazlar. Kant'ın sistemini tutarlı bir biçimde tamamlamak için yaptığı hamle, kaçınılmaz olarak kendi sisteminde bir sapmaya yol açar. Bu sapmayı ortaya çıkaran, Edmund Husserl'in terminolojisi ile söyleyecek olursak, "yaşam-dünyası" (Lebenswelt) (Husserl, 1970: 226) olarak estetik deneyimin mekânı ile birlikte, hem "imgelem" hem "zaman”, başka veçheleri ile ortaya çıkarlar. İmgelem ve zamanın bu yeni türden konumları, Kant'ın estetik teorisini, "düşünce-imgeleri” üreten bir pratik olarak film ile 
tekrar temas ettirir. 1790 yılında yayınlanan Yargı Gücünün Eleştirisi'nin amacı, "teorik akıl"ın (anlama yetisi) doğaya kendi a priori yasalarını ve ilkelerini empoze ederek bilgiyi yapılandırması gibi, yargı gücü de kendisine özgü yasa koyucu karakteri ile dünyaya değil ama kendisine yönelik a prori yasalar ve ilkeler ürettiğini ve böylelikle kendi kendisini belirlediğini gösterebilmektir. Teorik aklın dünyayı bilgi nesnesine indirgerken kullandığı "belirlenimci” yargı işlevinden tümüyle farklı bir biçimde, estetik deneyimde işlevsel olan "yargı" biçimi "belirleyici/belirlenimci" değil ama “düşünümsel/yanstıcı/reflektif”tir. Kant, "düşünümsel yargı gücü”nün bu türden, doğaya değil ama kendisine aşkınsal yasalar ve ilkeler koyma kapasitesini "heautonomi" (Heatonomie) olarak adlandırır (Kant, 1987: 180 ve 186). Benzer şekilde, Deleuze de sinemada "zaman-imgesi"ni görsel ve işitsel "heautonomi” olarak tanımlar ve onu "irrasyonel kesinti" kavramı ile birlikte düşünür (Deleuze, 2001b: 251-253). Burada vurgulanması gereken önemli noktalardan biri, Kant'ın "sanat/estetik" deneyimini "imgelem ve anlama yetisi arasında özgür uyum" ilişkisi üzerinden yapılandırmasının zorunlu sonucu olarak estetik haz veya duygu "kavramsal olmayan" bir çerçeveye oturtmasıdır. Kant'ın sistemi açısından buradaki güçlük, bilişsel kapasitelerin böylesi bir "kavramsal olmayan" çalışma prensibidir. Bu güçlüğü aşabilmek için Kant kendi metnini boydan boya kat ederken istikrarsız ve ilk bakışta irrasyonel ve paradoksal görünen kavramlar üretir: "Yasasız yasalılık", "Amaçsız amaçlılık", "belirlenimsiz belirlenim" vb. (ör. Kant, 1987: 241). Aslında buradaki kavramsallaştırmalar, Kant'ın estetik teorisinin temel referans noktasına, yani "kavramsız olma" niteliğine vurgu yapar. "Yasa", "amaç", "belirlenim” gibi nosyonlar anlama yetisinin kavramlarını zorunlu olarak ön-gerektirmektedir. Bu durumdan kaçınabilmek için Kant, daha önceki metinlerinde bulunmayan ikircikli-çelişkili kavramlar üretecektir. Ancak tam da bu çelişkili kavramlar yoluyla filmden alınan haz tanımlanabilecektir.

\section{Kant, Estetik ve Sanat}

Kant genel olarak yargı gücünü "tikeli genelin altına koyma kapasitesi" olarak tanımlar. Burada "genel" derken Kant'ın kastı "kavram, yasa veya kuraldır". Bu anlamıla epistemolojisini estetik teorisinden farklılaştırabilmek için iki yargı biçimini birbirinden ayırır: "Belirleyici/Belirlenimci Yargı" ve "Düşünümsel/Reflektif Yargı". (Burada 
"belirleyici" -Determinative- kavramını, "sınırlayıcı" olarak okumak, Kant'ın bağlamı açısından mümkün görünür.) Yargı'nın bu türden iki farklı görünümü ilk defa üçüncü Eleştiri ile gündeme gelir. Belirleyici yargı biçimi -ki bu birinci Eleştirinnin ana temalarından birisidir- Kant tarafından "objektif/nesnel yargı ya da "bilişsel yargı" olarak tanımlanır ve şimdiye kadar gündemimizde olan tek yargı biçimi yalnızca budur (Öte yandan, bu türden yargı biçimi için Kant'ın kullandığı haliyle "belirleyici yargı" adlandırması yine üçüncü Eleştiride ortaya çıkar). O, üçüncü Eleştiri'de belirlenimci yargının işlevini "tümelin verili olduğu durumlarda, tikeli bu tümelin altında/tümel yoluyla kavramak" olarak tayin eder (Kant, 1987: 179), bu anlamıla belirleyici yargı anlama yetisinin kavramlarının istisnasız tahakkümü ile çalışır (Kant, 1965: A 133-136, B 170-175). Böylece belirleyici yargı, anlama yetisinin kendine ait hegemonik gücü ile deneyimin nesnelerini hem kurduğu/belirlediği hem de düzenlediği son derece sınırlandırıcı bir sürecin (bilme süreci) rutin, tekdüze ve sıradan parçası olarak işlev görür. Bilişsel süreçte anlama yetisi, kendi aşkınsal yasalarını ve kurallarını yalnızca bilinir dünyanın nesnelerine değil ama aynı zamanda yargı gücüne ve imgeleme de dayatır. Bu haliyle yargı ve imgelem, anlama yetisi ve onun yasaları/kavramları tarafından kolonize edilir. Yargı gücünün bilişsel kullanımı dışında, üçüncü Eleştirisinde, yani sanat ve estetik deneyimde ise Kant, yargı gücüne son derece müstesna bir işlev atfeder ve ona kendi ilkelerini ve kurallarını sunar. Buna göre, tikelin verili olduğu ve yargı gücünün bu tikel için bir tümel bulmak zorunda olduğu durumda, bu yeti yalnızca düşünümsel/reflektif olabilir, belirleyici değil. Burada reflektif yargı, anlama yetisinin kavramları (tümel-genel) olmaksızın çalışır, tikel olanı bilgi nesnesine indirgemez/sınırlamaz veya belirlemez, yalnızca deneyimler. Böylelikle doğa/dünya ve şeyler, anlama yetisinin belirlenim ilişkisinden kurtulur ve kendi canlılığı, çoğulluğu, üretkenliği içerisinde, anlama yetisinin soyutlamasına indirgenmeksizin deneyimlenir (Kant, 1987: 203-212). Çok açıktır ki bu yeni tür deneyim biçimi, bilişsel veya sıradan değil, özel ve estetik bir performansa işaret eder. Kant, belirleyici yargının, anlama yetisinin yasaları/kavramları altında yalnızca şematik bir biçimde çalıştığına, düşünümsel/reflektif yargının ise kendi yasası uyarınca teknik bir şekilde çalıştığına vurgu yaparken (Kant, 1987: 248), ilk durumda doğa/dünya hakkındaki yargının anlama yetisinin belirleyici ve kurucu yasaları ve ilkeleri yoluyla ulaşıldığına, ikinci durumda ise doğaya/dünyaya kendi heterojen çoğulluğunu soyutlamaksızın dinamik 
ve üretken bir çeşitlilik olarak yaklaşıldığını teminat altına almak ister. Kant açısından, “düşünümsel yargı"ya yönelik gereklilik, "yaşam”-“doğa” kendi başına -bir bilgi nesnesi olarak kavranmaksızın- sonsuz bir çeşitlilik olarak tanımlandığında kaçınılmaz olarak ortaya çıkar. Bu haliyle yaşam, bizim onu soyutlayarak/indirgeyerek kavramamızın ötesindedir. Dolayısıyla, anlama yetisinin a priori ve evrensel yasaları/ilkeleri yaşamın bu sonsuz çeşitliliğini, onun tikel formlarını kapsamaktan/kavramaktan uzaktır. Kant'ın metin boyunca yürütmüş olduğu argümanları genelleyerek ifade edecek olursak, zihnimiz, yaşamın çeşitliliğini, bir başka ifadeyle, yaşamdaki farklılıkarı, kavramak için yetersizdir.

O halde, bu türden bir yaşamsallık içerisinde estetik deneyim ve bu deneyimdeki "haz duygusu" ve "beğeni yargısı" nasıl ortaya çıkar? Kant estetik deneyimi bilişselrutin deneyimden ayrıştırmak için, beğeni yargısında "bilişsel kapasitelerin" farklı bir biçimde çalıştığını belirtir (Ör. Kant, 1987: 287). Estetik düşünümsel yargıda, "imgelem", anlama yetisinin belirleniminden ve sınırlamalarından tümüyle azadedir. Kant bu durumu "özgür uyum" kavramı ile tanımlar. Kant'ın ifadesiyle, bilişsel ve rutin deneyimde "imgelem anlama yetisinin hizmetinde iken, estetik deneyimde anlama yetisi imgelemin hizmetine girer (Kant, 1987: 242). Tam bu noktada, Deleuze'ün modern sinemaya referansla yapmış olduğu "zaman-imgesi" ve "hareket-imgesi" arasındaki ayrım kristalize olur. Nasıl ki Kant açısından epistemolojik ve estetik deneyimde imgelem ve anlama yetisinin konumları altüst oluyorsa, aynı şekilde Deleuze açısından da "hareket-imgesi"nde zaman harekete eklemlenir, yani hareketin egemenliği altında dolaylı olarak var olur, öte yandan "zaman-imgesi”nde ise zaman, hareketin bu tahakkümünden kurtulur ve hareketin kendisi zamana eklemlenir, onun hizmetine girer (Deleuze, 2001b: 271). Ulus Baker, son derece isabetli analizinde, Kant'ın estetik teorisinde belirlenimci aklın imgelem tarafından "aşıldığını" vurgular. Baker açısından, Kant'ı Spinoza'ya yaklaştıran imgelemin aklı aşan bu konumdur (Baker, 2014: 163). Tekrar Kant'ın estetik teorisine geri dönersek, dolayısıyla estetik deneyimde imgelem, duyu nesnesini alımlarken anlama yetisinin kavramları yoluyla onu şematize etmez/belirlemez, estetik hazzı ortaya çıkaran deneyimde, tam tersi bir biçimde, imgelem ve anlama yetisi özgür bir uyum içerisine girer. Dieter Heinrich söz konusu özgür uyumu "hareketlerinde birbirlerini etkilemeden uyum sağlayan ve ortak performanslarından haz alan iki ikişinin dansı" olarak nitelendirir (Heinrich, 1969). 
Buradaki güçlük, estetik teorisinin neredeyse bütün yükünü taşıyan böylesi merkezi bir temayı Kant'ın ayrı bir başlık altında ve detaylı bir biçimde ele almamasından kaynaklanır. İlgili literatürde öne çıkan yorumlar açısından, imgelem estetik deneyimde hala "şema" oluşturmakta ancak bunu anlama yetisinin kavramlarının belirleyiciliği olmaksızın gerçekleştirmektedir (Hughes, 2006: 557-560). Beğeni yargısını ortaya çıkaran nesnenin "ne" olduğu -ki bir tanımı ve dolayısıyla kavramı zorunlu kılar- özne açısından bütünüyle gündem dışıdır. "Bu bir fotoğraftır" yargısı, anlama yetisinin kavramının belirleyiciliği, tanımlamasını gerektirirken, "bu güzel bir fotoğraftır" yargısında bulunurken nesnenin "ne" olduğu, Kant açısından, beğeni yargısını belirleyen bir moment olmamalıdır. "Estetik düşünümsel yargı"nın ortaya çıkabilmesi için "kavramsızlık" gerekli ama yeterli koşul değildir. Ek olarak veya daha doğru bir ifadeyle, kavramsız olmanın zorunlu ve mantıksal sonucu olarak, Kant çeşitli parametreler belirler. Buna göre, estetik deneyim her türden kişisel çıkarı/ilgiyi, nedensel ilişkiyi, belirlenimi dışlar. Bu türden kendine münhasır bir deneyim, "çıkarsızlığı", "tefekkür”ü, salt seyiri ve "amaçsız bir amaçlılığı" zorunlu kılar (Kant, 1987: 205-231). Bir başka şekilde söylendiğinde, Kant'ın estetik teorisinin bütün ağırlığını taşıyan bu yapıtaşlarından birinin noksanlığı bütün bir sistemin kaçınılmaz olarak çökmesine sebebiyet verir. Aslında, Kant tarafından en başından estetik teori kavramsal belirlenimden azade bir biçimde kurgulandığından bütün bu öğeler birbirini gerektirir ve her biri "kavramsal belirlenim" olmaksızın teorinin kendi içsel bütünlüğünü ve dayanağını sağlar. Bu anlamıyla, Kant'ın estetik teorisi kendi içinde tamamlanmış bir sistem olarak ortaya çıkar. Kant'ın kendi terminolojisini ödünç alarak ifade edecek olursak, bütün bu öğeler bir diğerinin Ratio Essendisi, bir diğeri, geri kalan bütün öğelerin Ratio Cognoscendisidir. Buradaki parametrelerden "ilgisizlik-çıkarsızlık" (disinterestedness) koşulu, Kojin Karatani tarafından Kant estetik teorisi ile Marcel Duchamp'ın sanat anlayışını ortaklaştıran kritik bir tema olarak değerlendirilir. Karatani modern sanat tarihinde kabul gören bir saptamayı tekrar ederek, Duchamp'ın "Çeşme" adını verdiği hazır-yapıtında kullandığı "pisuvar"ın sanat nesnesi niteliği kazanabilmesinin ilksel koşulunun söz konusu objenin gündelik kullanımının "paranteze alınması” olduğunu belirtir. Tıpkı bunun gibi, Kant için, "ilgisizlik" ya da "çıkarsızlık”, estetik-sanat nesnesinin gündelik çıkarlarının paranteze alınması edimine işaret etmektedir (Karatani, 2008: 150). Buradaki tartışma, Deleuze'ün yukarıda 
alıntıladığımız kritik pasajındaki vurguyu akıllara getirir. Deleuze açısından da algı, ekonomik ya da gündelik çıkarlar tarafından asimile ediliyor ve yönlendiriliyordu. Sinematik aygıtı klişe üreten makineye dönüştüren koşul yine bu türden çıkarlar idi. $O$ halde, film ile kurulan ilişki, eğer bu bir tür sanatsal-estetik ilişki biçimi ise, kişisel çıkar ya da ilgiyi iptal etmek zorundadır. Böylece, eğlence amacıyla, kişisel bir çıkar için deneyimlenen film izleme pratiğinin nesnesi olan ve bu talebi klişeler üreterek yerine getiren filmler ile, deneyimi çoğullaştıran ve üreten filmleri birbirinden ayıracak belirgin bir referans noktası elde etmiş oluruz. Kant, daha önceki metinlerde pek sık karşılaşmadığımız bir biçimde, gündelik hayattan örnekler vererek estetik teorisindeki argümanlarını "yaşam” üzerinden sınamaya tabi tutar. Örneğin, "müzik” tartışmasını yürütürken estetik deneyimin nesnesi olabilecek müziği "partilerde eğlence amaçlı çalınan standart ve sıradan müzik"ten kesin bir biçimde ayırır. İlkinde müzik, kişisel çıkarı ve ilgiyi tatmin ederken, ikincisinde müzik, bu türden belirlenimlerin tümüyle dışında yalnızca estetik fikir yoluyla haz duygusu üreten bir etkinlik olarak var olur (Kant, 1987: 332). Kant bir başka bölümde doğadaki kuş sesi ile kültürel bir üretim olarak müziği kıyaslarken, "doğanın sonsuz çeşitliliğine ve kuralsız güzelliği”ne vurgu yaparak "çeşitliliği, farkı, kuralsızlığı, rutinsiziliği ve alışkanlığı yaran standart dışılığı” estetik deneyimin ve haz duygusunun temel bileşenleri olduğunun altını çizer (Kant, 1987: 243). Devamında seyir nesnesi olarak ateşin hareketlerindeki rutin dışı değişiklikler üzerinden anlık ve beklenmedik sapmaların/değişimlerin estetik haz duygusunu imgelemin özgür üretimi ile ilişkilendirerek nasıl harekete geçirdiğini anlatır. Rutini, standart olanı, klişeyi, tekdüzeliği yadsıyan ve bu rutin dışılığı-kuralsızlığı anlama yetisinin tahakkümünden kurtularak özgür biçimde algılayan imgelemi yücelten buradaki Kantçı vurgu tam da Deleuze'ün altını çizdiği rutinin, tekdüze olanın, standart duyusal-motor bağlantısının irrasyonel kesintiler ile alt-üst edilmesi ve böylelikle sinema tarafından içerilen "düşünce"nin üretildiğine yönelik iddiayı neredeyse tümüyle onaylar.

Buraya kadar Kant'ın estetik teorisinin, imgelem, standart olandan sapma, rutin dışılık bağlamında Deleuze'ün film teorisi ile olan güçlü bağını gördük. Ancak Kant'ın estetik teorisindeki "zaman" kavramının "film" ile veya "film izleme pratiğinde ortaya çıkan haz duygusu" ile olan müphem bağı doğru bir biçimde kurabilmek için hala bir miktar daha "zamana" intiyacımız var. Kant, "beğeni yargısı estetiktir" der. Tanımı şu 
şekilde tercüme etmek de mümkün görünüyor: "Sadece beğeni yargısı estetiktir”. Kant, "beğeniyi”, "öznenin güzel olan hakkında haz duygusu yoluyla yargıda bulunma kapasitesi" olarak tanımlar. Estetik deneyimde bir nesne hakkında güzel yargısında bulunduğumuzda nesnenin formunun algısını, yani bizim haz duyumuzu yine kendimizle, bir başka deyişle, bizdeki haz duygusuyla ilşkilendiririz, o nesnenin kavramıyla değil. O halde, estetik deneyimde nesnenin formu/biçimi imgelem tarafından alımlanır, ancak nesnenin bu formu onu bilme nesnesi kılmak üzere anlama yetisinin belirlenimci kavramıyla ilişkilendirilmez. Bir başka ifadeyle söyleyecek olursak, estetik deneyim ve buna bağlı olarak üretilen haz duygusunun ortaya çıkması için iki temel koşul Kant tarafından zorunlu tutulmuştur: 1. İmgelem alımladığı duyu verisini anlama yetisinin belirleyici ve sınırlayıcı kavramına taşıyamaz 2. Buna bağlı olarak epistemolojik anlamda "tanıma/bilme gerçekleşmez". Kant'ın burada neyi kastettiği, buradaki mekanizmanın nasıl çalıştığı yine Kant tarafından bütünüyle cevapsız bırakılır. Dolayısıyla literatürde büyük bir tartışma başlar. Bu tartışmalarda kendisine taraftar bulan hakim yorumlardan bir tanesine göre, estetik düşünümsel yargıda da zihnin iki temel yetisi ile (yani imgelem ve anlama yetisi) standart işlevleri gereği "epistemolojik tanıma amaçlanır" ancak bu gerçekleşmez/kesintiye uğrar ve estetik haz duygusu ortaya çıkar. Beatrice Longuenesse bu durumu "tanıma/bilme başarısızığı" olarak tanımlar (Longuenesse, 2000: 162-168). Bu durumu ilk koşula tercüme ederek söyleyecek olursak, imgelem ve anlama yetisi arasındaki mantıksal ve rutin işlev irrasyonel ve beklenmedik bir biçimde kesintiye uğrar. Bir başka ifadeyle, imgelem, bilme/tanıma süreci sırasında, mekanik algılama sırasında, rutin-standart bir biçimde uyguladığı duyu verilerini anlama yetisinin kavramlarına taşırken "irrasyonel bir biçimde kesintiye uğrar”. Buradaki tartışma, Kant'ın estetik teorisinin çalışma prensibini ve haz duygusunun ortaya çıkışı koşullarını doğrudan ve yorumlamaya yer bırakmaksızın Deleuze'ün ele aldığı biçimiyle film fenomenine bağlar. Deleuze, duyusal-motor şemanın kurduğu standart bağlantıların "irrasyonel kesintilere" uğramasını "zaman-imgesi ve hareket-imgesinde" ortaya çıkan "düşüncenin" temel koşullarından bir tanesi olduğunu tekraren vurgular. İkinci olarak, Bergson bağlamında yürüttüğü tartışmada, bu irrasyonel kesintiler, rutin dışına çıkışlar yoluyla klişelerin ve alışkanlığın kırıldığını ve dolayısıyla "tanımanın başarısızlığa uğrayarak" düşünceimgesinin üretimini mümkün kıldığını belirtir (Deleuze, 2001b: 55). Yani, sinema 
deneyiminde, bilincin film ile temasında "tanıma/bilme" gündem dışıdır, buradaki deneyim epistemolojik bir amacı kaçınılmaz olarak dışlayacaktır.

\section{Kant ve Sanat Olarak Sinema}

Böylelikle Kant'ın estetik teorisinde "zaman"ın ayrıcalıklı konumuna ve bunun film teorisi ile olan ilişkisine geliyoruz. Aslında, Kant'ın estetik teorisinde nesnenin "formubiçiminin" merkezi konumu, zamandan ziyade uzamı temel mesele haline getirir. Öte yandan, estetik deneyimde "amaçsız amaçlıık"ın içerildiğini de yukarıda belirtmiştik. Burada haz duygusunu ortaya çıkaran koşul olarak "amaçsız amaçlılık" nosyonu özel türden bir zaman kavramına yönelik ihtiyacı da görünür kılar. Bir başka ifadeyle estetik deneyim sırasında, zamanın ardışık ve doğrusal olma durumunda irrasyonel bir sapma meydana gelir. Kant "güzellik" nosyonunu bir de şu şekilde tanımlayacaktır: Güzellik, amacın kendisi imgelem ve saf duyu verileri tarafından sunulmaksızın, nesnede algılandığı sürece nesnenin formunun amaçsallığıdır (Kant, 1987: 236). Burada “amaç" (Alm. Zweck, İng. Purpose), bu kavramı "nesnenin nedeni” olarak kavradığımız koşulda "bir kavramın nesnesidir". "Amaçsallık" (Alm. Zweckmäßigkeit, İng. Pursposiveness) ise nesnenin "nedenselliğidir" (Alm. Causalitat, İng. Causality). Dolayısısyla Kant açısından estetik yargıda amaçsallık bir neden, yani kavram, olmaksızın, yani amacın kendisi olmaksızın amaçsallık olmalıdır ve bu durum "nedensiz nedensellik" anlamına da gelmektedir. Aslında Kant'ın burada yürütmüş olduğu son derece yoğun tartışmada kurmak istediği denklem, "amaç"ın "kavram"a ve "neden"e (cause), "amaçsallığın” ise "kavramsız bir nedenselliğe” denk düştüğüne işaret eder. Bu denkleme göre "amaçsallık" aynı zamanda ve kaçınılmaz olarak "bir nedensellik ilişkisinde 'sonuç-etki'ye karşılık gelecektir. Bildiğimiz üzere estetik deneyimde haz duygusu kesinlikle herhangi bir nedensel ilişki içerisinde bulunamaz. Öte yandan bir amaç, "nihai neden" olarak nesnesini ön belirler. Burada da bir belirleme ilişkisi olduğu için estetik deneyimde bir amaçtan bahsedemeyiz. O halde, "amaçsız amaçlılık" estetik deneyimde ne ifade etmektedir? Paul Guyer son derece isabetli bir biçimde Kant'ın estetik teorisinde "neden" ve "sonuç" arasındaki zamansal ilişkinin bozulduğu tespitinde bulunur (Guyer, 1997: 191-198). Gerçekten de, bu tanımlardan hareketle yorumlandığında, estetik deneyimde "neden ve sonuç" arasındaki zamansal (ardışık) belirlenim kaçınılmaz olarak tersine çevirilir. Bilişsel 
süreçte, nedensellik ilişkisi içerisinde imgelem ve zaman, neden ve sonucu zorunlu bir biçimde ardışıklık, "öncelik ve sonrasılık" olarak kavrarken, bir başka ifadeyle, epistemolojik ya da rutin deneyimde bir "neden" istisnasız bir biçimde zamansal olarak "sonuç"tan önce gelirken, estetik deneyimde "sonuç", yani "amaçsallık", kendi “neden”inden önce gelir. Estetik düşünümsel yargının temel koşulu olan "yetilerin (imgelem ve anlama yetisi) özgür oyununda" zaman artık ardışık değildir. Düşünce, "sonuç”tan, yani "amaçsallıktan”, "neden"e yani "amaca” doğru gider ve tekrar geri gelir. Buradaki "gitme ve geri dönme" hareketinde artık "zaman" harekete tâbi değildir. Tam tersi bir biçimde, hareketin kendisi zamana tabidir. Bu noktada, Kant'ın estetik teorisinde ortaya çıkan "zaman" ile ve Deleuze'ün sinemada "gördüğü" zaman arasındaki koşutluğu tekrar fark ederiz. Hatırlayacağımız üzere Deleuze, zamanimgesini hareket-imgesinden ayırırken son derece kritik bir vurgu yapmış ve modern sinemanın ürettiği imgelerde artık zaman'ın harekete eklemlenmediğini, hareket yoluyla ortaya çıkmadığını, aksine ondan bağımsız, dolayımsız olarak ortaya çıktığını vurgular. Kant bağlamında burada vurgulanması gereken bir diğer önemli husus, estetik deneyimde söz konusu olan "zaman"ın kesintiye uğraması değil, tersine, içiçe geçtiğine yöneliktir. Kant'ın vurguladığı gibi estetik nesnenin sunumu ve estetik deneyimin kendisi "şimdi"de gerçekleşir. Ancak bu deneyimi mümkün kılan zihinsel süreçler ve haz duygusunun kendisi aynı anda ve eşzamanlı olarak "şimdi”yi, "geçmiş"i ve "gelecek"i içerir. Yetilerin bu özgür oyununda, amaçsallıkla karşılaşıldığı zaman, amaca yönelme gerçekleşir, "amaç" bu anlamıyla her zaman için "gelecek"te asılı olarak kalır, gelecek bu hamlede "şimdiyi” kapsar ancak "amaçsallığın" sunulma anı olarak "geçmiş" geri de bırakılmış değildir. Kant bu tartışmaları yürüttüğü ilgili bölümde son derece girift ve kritik bir argüman ileri sürer (Kant, 1987: 222):

Estetik yargıda bilinç, öznenin hem bilişsel yetilerinin canlandırılması hem de genel olarak bilişsel olanla ilgili özel bir tür nedensellik (Inner Causality, ki bu aynı zamanda "amaçsallık"tır) için bir temel/zemin içerir.....Dolayısıyla da, sunumun-verişinin (presentation) öznel amaçlılığının yalnızca bir biçimini içerir. Oysa içerisinde, bizi sunumun-verilişinin kendisi durumunda tutması ve bir başka amaç olmaksızın bilişsel yetilerin bu durumda kalması, bu durumu sürdürmesi için, bir nedensellik barındırır (Causalitat in sich). Güzeli deneyimlerken bu seyirde/tefekkür halinde kalırız, bu halin geçmesini geciktirir orada salınırız, çünkü bu seyir kendi halini pekiştirir ve yeniden üretir. 
Dolayısıyla tıpkı Deleuze'de olduğu gibi, Kant açısından da hem estetik deneyimin kendisi hem de haz duygusu istismar edilen bir konum değil, tersine, son derece üretken bir edimdir. Nihai olarak, estetik deneyimde ortaya çıkan "haz duygusu", “yaşam duygusu”nun karşılığıdır. Dahası, Kant, haz duygusunu üreten şeyin bu deneyimde, yetilerin bu özgür oyununda kalma/salınma halinin bizatihi kendisi olduğunu vurgular (Kant, 1987: 220). İşte, yetilerin özgür oyunundaki buradaki "salınma hareketi", zamanın, Bergsoncu anlamıyla, matematikselleştirilmişuzamsallaştırılmış formunda, Kantçı anlamıyla imgelemin anlama yetisinin tahakkümü altında gerçekleşen şematik işlevi yoluyla, ardışık olarak gerçekleşmez. Burada, özel bir tür "zaman" kavramıyla karşı karşıyayızdır. Literatürde fazla değinilmeyen, ancak estetik deneyimde "zaman"ın konumunu tespit etmek için okuyucuya yol gösterici olabilecek bir hamleyi Kant Antropology metninde yapar. Bu metinde Kant haz duygusu ile ilişkilendirerek zamanın bir başka veçhesini "iç dünyanın zaman formu"ndan (interior sense) bahseder. Burada artık zaman bilme faaliyetinin dışında, "sezgisel” ve "duyarlı" bir biçimde çalışır (Kant, 1996: 153-154).

\section{Sonuç}

Kant üçüncü Eleştiri'sinde, film ya da bedende konumlanan edimsel-bilişsel algı bağlamında yukarıda yürüttüğümüz tartışmaya paralel olarak, algılamamızın epistemolojik etkinlikte olduğu gibi tahakküm kurucu, standart ve rutin olmadığını, dolayısıyla "bilinmeyeni” "bilinen"e indirgeyerek standardize etmediğini/homojenleştirmediğini ısrarla vurgular. Kant, sanat ya da estetik deneyimde, bir başka ifadeyle, yetilerin özgür oyununda ve haz duygusunda tüm rutinlerin kırılmaya uğradığı ve alışkanlığın sekteye uğradığı sıradışı ve epistemolojik anlamda neredeyse irrasyonel bir momenti ima eder. Estetik nesne ile temas ettiğimizde, onu "bilinir" kılmayız, kendi tefekkürümüzde yalnızca "hissederiz". Deleuze, "Düşünce ve Sinema" başlığı altında öznenin film ile temas ettiği sinema deneyimini tartışırken [bu bölümde "Yüce" başlığı altında sinemadaki "şok" halini doğrudan Kant'ın ismini zikrederek ve Kantçı terminoloji ile tarışır. Ör. "Matematiksel Yüce" ve "Dinamik Yüce" (Bkz. Kant, 1987: 248-271)] bu deneyimin temel niteliğinin, 
ampirik bir "Görüyorum" ya da "Duyuyorum" değil, aksine, "HiSSEDiYORUM"8 duygusu olduğunun altını dikkatler çizer. Bu türden "Hissediyorum"un Kartezyen bağlamından tümüyle koparılmış karşılığını ise "Sinematografik DÜŞÜNÜYORUM"dur' (Deleuze, 2001b: 158). Kant açısından da, birinci Eleştirisine sirayet eden özne-nesne ilişkisi (yani nesne epistemolojik bilgi nesnesi olarak yapılandırılırken aynı zamanda özne de bilişsel özne olarak kurulur) üçüncü Eleştirı’de çözülmeye uğrar ve dağılır. Diyebiliriz ki, artık estetik deneyimin öznesi, epistemik özne gibi matematiksel-soyut-evrensel bir kategorik özne değil, deneyimi "o anda yaşayan ve hisseden" tekil, somut, yaşayan, hisseden organik bir öznedir. Deneyimin çoğullaştığı film ile temas eden özne, anonimlikten kurtularak kendisini film ve düşünce-imgesi dolayımıyla yeniden üretir ve tekilleşir.

Gördüğümüz üzere, "amaçsız amaçlılık" ya da "haz duygusu”nun performe edildiği "zamansallık" tartışılırken, "geçmiş, şimdi ve geleceğin" matematiksel bir ardışıklık olarak kavranamayacağını vurguladık. Deleuze, hareketli görüntü olarak filmde, zamanın birbirini dışlayan birimler olarak "ardışıklık" (image after image) olarak sunulmadığını tersine birbirini içeren bir akış olarak (image plus image) içerildiğini vurgular (Kant, 1987: 214). Bir başka ifadeyle, hareketli görüntü olarak filmde, "geçmiş, şimdi ve gelecek" aynı anda, eşzamanlı olarak var olur (Deleuze, 2001b: 37). Dolayısıyla Deleuze açısından, Bergson'un "sinematografik imge"yi "matematikseluzamsal zaman" ile eşitleyerek olumsuz bir okuma yapmasına yol açan sebep, Bergson'un filmde içerilen "hareket-imgesi" ve "zaman-imgesi"ni doğru değerlendirememesinden kaynaklanır. (Öte yandan, İkinci Dünya Savaşı sonrasına tarihlenen "zaman-imgesi"ni Bergson'un değerlendirmesi tarihsel olarak mümkün değildi). Ulus Baker, Kant'ın estetik teorisindeki argümanları ile Spinoza'ya yaklaştığını belirtmişti (Baker, 2014: 163). Burada bir adım daha ileri giderek, Kant'ın estetik teorisinin Bergson'a da yaklaştığını, hatta onunla temas ettiğini iddia etmek mümkün görünmektedir. Kant'ın epistemeolojisinde ele alınan haliyle zaman, Bergson'un sistemindeki "matematikselleştirilmiş-uzamsallaştııılmış" mekanik zaman'a karşılık gelirken, estetik kuramındaki haliyle zaman, geçmiş, şimdi ve gelecek içiçe geçmiş bir akış olarak "süre"ye denk düşer. Benzer şekilde ama farkıı bir bağlamda Szaloky, 
Deleuze'ün sinema teorisini tartışırken Kant ile Bergson arasındaki kurulabilecek bağlantıya işaret eder. Buna göre Szaloky, Kant'ın "epistemolojik yargı" ile "reflektif yargı" arasında öngördüğü ayrımın Bergson'un duyusal-motor şeması tarafından üretilen "otomatik-alışkanlıktan kaynaklı tanıma" ile "dikkatli tanıma" arasında yaptığı ayrıma denk düştüğünü öne sürer. Bergson ile Kant arasında kurulan bu türden bir koşutluk da Deleuze'ün sinema teorisini Kant'ın estetik teorisine bir adım daha yaklaştırır (Szaloky, 2010: 61-62). Bu makale boyunca tartışmaya çalıştığımız gibi, Kant'ın estetik teorisini kurarken merkezine aldığı "amaçsız amaçlılık", "kavramsız nedensellik", "şemasız şematizm" gibi paradoksal kavramlar, "irrasyonel kesinti"yi bu teoriye dışarıdan eklemlenen "ikincil bir tema" olmaktan çıkartır ve onu Kantçı estetik deneyime "içkin" bir zorunluluk olarak kayıt altına alır. "İrrayonel kesinti” nosyonu aynı anda Deleuze'ün film teorisinin tamamına sirayet eder ve "zaman-imgesi"nin temel niteliklerinden biri olarak konumlanır. Bütün bu tartışmalar ışığında fark ederiz ki, hareketli görüntü olarak film ve içerdiği eşsiz "zamansalık", Kant'ın estetik teorisinin yalnızca çeperinde göz ucuyla görünmez. O, bu teorinin aynı zamanda muamma koşuludur. Bir film izlerken izleyicide haz duygusunu oluşturan şey, deneyimlediğimiz Bir ve Üç Sandalye'dir. 


\section{Kaynakça}

Adorno, Theodor, W. (2006). Aesthetic Theory. Minneapolis: University of Minnesota Press.

Althusser, Louis (2006). Devletin Ideolojik Aygıtları. Çev., Alp Tümertekin. İstanbul: İthaki Yayınları.

Andrew, Dudley J. (1976). The Major Film Theories. Oxford: Oxford University Press. Baker, Ulus (2014). Sanat ve Arzu. İstanbul: İletişim.

Berger, John (2005). Görme Biçimleri. Çev., Yuardanur Salman. İstanbul: Metis.

Bergson, Henri (1998). Creative Evolution. New York: Dover Publication.

Colebrook, Claire (2004). Gilles Deleuze. Ankara: Bağımsız Kitaplar.

Crary, Jonathan (2015). Gözlemcinin Teknikleri. Çev., Elif Daldeniz. İstanbul: Metis.

Copjec, Joan (1994). Read My Desire: Lacan against the Historicists. Massachusetts:

The MIT Press.

Deleuze, Gilles (1995). Kant'ın Eleştirel Felsefesi. Çev., Taylan Altuğ. İstanbul: Payel.

Deleuze, Gilles (1999). Kapitalizm ve Şizofreni. Çev., Özcan Doğan. Ankara: Araf.

Deleuze, Gilles (2001a). Cinema 1: The Movement-Image. Minneapolis: University of Minnesota Press.

Deleuze, Gilles (2001b). Cinema 2: The Time-Image. Minneapolis: University of Minnesota Press.

Guyer, Paul (1997). Kant and the Claims of Taste. Cambridge: Cambridge University Press.

Heinrich, Dieter (1969). "The Proof Structure of Kant's Transcendental Deduction." Review of Metaphysics, 22(4): 640-659.

Hughes, Fiona (2006). "On Aesthetic Judgment and Our Relation to Nature: Kant's Concept of Purposiveness." Nous, 49(6): 547-572.

Husserl, Edmund (1970). The Crisis of European Sciences and Transcendental Phenomenology. Çev., David Carr. Evanston: Northwestern University Press. Kabadayı, Lale (2015). "Sinemada Felsefe ve Film Felsefesi Üzerine." Doğu Batı 1: 89-116.

Kant, Immanuel (1965). Critique of Pure Reason. Çev., Norman K. Smith. Boston:

Betford \& St. Martin's.

Kant, Immanuel (1987). Critique of Judgment. Çev., Werner S. Pluhar. Indianapolis: 
Hackett.

Kant, Immanuel (1996). Antropology from a pragmatic Point of View. Southern Illinois University Press.

Karatani, Kojin (2008). TransKritik: Kant ve Marx Üzerine. Çev., Erkan Ünal. İstanbul: Metis.

Kosuth, Joseph (1965). One and Three Chairs.

https://www.moma.org/audio/playlist/1/49, Erişim tarihi: 25.12.2019.

Lazzarato, Maurizio (2016). Video Felsefe. Çev., Şule Çiltaş Solmaz. İstanbul:

Otonom.

Longuenesse, Beatrice (2000). Kant and the Capacity to Judge: Sensibility and

Discursivity in the Transcendental Analytic of the Critique of Pure Reason. New York: Princeton University Press.

McGowan, Todd (2012). Gerçek Bakış. Çev., Zeynep Özen Barkot. İstanbul: Say Yayınları.

McGowan, Todd ve Sheila Kunkle (2014). Lacan ve Çağdaş Sinema. Çev., Yasemin Ertuğrul ve Caner Turan. İstanbul: Say Yayınları.

Mulvey, Laura (2008). "Görsel Haz ve Anlatı Sineması." Sanat, Cinsiyet: Sanat Tarihi ve Feminist Eleştiri. Ahu Antmen (der.) içinde. İstanbul: İletişim. 277-299.

Öztürk, Serdar (2017). Sinema Felsefesine Giriş: Film-Yapımı Felsefe. Ankara: Ütopya.

Rodowick, D. N. (1997). Gilles Deleuze's Time Machine. Londra: Duke University Press.

Sinnerbrink, Robert (2014). "Hugo Münsterberg." Film, Theory and Philosophy: The

Key Thinkers. Felicity Colman (der.) içinde. New York: Routledge. 20-29.

Szaloky, Melinda (2010). "Mutual Images: Reflections of Kant in Deleuze Transcendental Cinema of Time." Afterimages of Gilles Deleuze's Film

Philosophy. D. N. Rodowick (der.) içinde. Minneapolis: University of Minnesota Press. 47-75.

Wheatley, Catherine (2009). Michael Haneke's Cinema: The Ethics of the Image. New York: Berghahn Books.

Yaren, Özgür (2006). "Sinemasal Yüce: Felaket Filmlerinde Yüce Arayışı”. Kültür ve Iletişim, 9(2): 63-80. 
Zinkin, Melissa (2003). "Film and Transcendental Imagination: Kant and Hitchcock's The Lady Vanishes." Imagination, Philosophy and the Arts. Dominic Lopes ve Matthew Kieran (der.) içinde. Londra: Routledge. 245-258.

Zizek, Slavoj, (2006). Kırılgan Temas. Çev., Tuncay Birkan. İstanbul: Metis. 